\title{
Cognitive and psychological sequelae of hydrocephalus and spina bifida: correlating subjective data and objective neuropsychological data to establish insight and inform clinical intervention and guidelines

\author{
Trudi Edginton*1,2,3, Jo Iddon1,2, Catherine Loveday1,2,3, John Pickard ${ }^{2}$ and
} Richard Morgan ${ }^{1}$
}

\author{
Address: ${ }^{1}$ Department of Medicine \& Therapeutics, Level 4, Chelsea and Westminster Hospital, 369 Fulham Road, London, SW10 9NH, UK, \\ ${ }^{2}$ Department of Academic Neurosurgery (Box 167), Addenbrooke's Hospital, Cambridge, CB2 0QQ, UK and ${ }^{3}$ Department of Psychology, \\ University of Westminster, Regent Street, London W1B 2UH, UK \\ Email: Trudi Edginton* - t.edginton@wmin.ac.uk \\ * Corresponding author
}

from 53rd Annual Meeting of the Society for Research into Hydrocephalus and Spina Bifida Belfast, UK. 24-27 June 2009

Published: 27 November 2009

Cerebrospinal Fluid Research 2009, 6(Suppl 2):S7 doi: 10.I I86/I743-8454-6-S2-S7

This abstract is available from: http://www.cerebrospinalfluidresearch.com/content/6/S2/S7

(C) 2009 Edginton et al; licensee BioMed Central Ltd.

\section{Background}

Despite significant advances in treating and improving the prognosis of individuals with hydrocephalus and spina bifida, many of these individuals continue to experience specific cognitive difficulties in the areas of memory, language, attention and executive function and these can often have a significant negative impact on everyday functioning [1-3].

\section{Materials and methods}

A comprehensive questionnaire was designed, based on known cognitive and emotional sequelae, to assess patient and caregiver perceptions of the specific difficulties experienced by people with hydrocephalus and spina bifida and the extent to which these are being addressed. In order to establish levels of insight, this questionnaire was correlated with detailed neuropsychological data to triangulate actual cognitive performance with subjective self-assessment obtained from patients and the objective view of caregivers.

\section{Results}

Questionnaire data will be presented that will highlight specific areas of discrepancy and concordance between patients and their caregivers $(n=60)$ and will be discussed in relation to actual performance on a range of cognitive tasks and the subsequent implications for strategic advice and intervention.

\section{Conclusion}

The data is being used to tailor specific cognitive strategies based on enhanced self-awareness, as part of small group and individual cognitive training interventions, within a multidisciplinary setting. It is hoped that the dissemination of the materials and methods designed for this study will inform best practice guidelines for these individuals and their caregivers and provide measurable outcomes for cognitive performance discrepancy, meta-awareness, strategy implementation and evaluation.

\section{References}

I. Iddon JL, Morgan DJ, Sahakian BJ: Cognitive dysfunction in patients with congenital hydrocephalus and spina bifida: evidence for a dysexecutive syndrome? Eur J Pediatr Surg 1996, 6(Suppl I):4I.

2. Iddon JL, Morgan DJ, Ahmed R, Loveday C, Sahakian BJ, Pickard JD: Memory and learning in young adults with hydrocephalus and spina bifida: specific cognitive profiles. Eur J Pediatr Surg 2003, I3(SuppI I):S32-S35.

3. Iddon JL, Morgan DJ, Loveday C, Sahakian BJ, Pickard JD: Neuropsychological profile of young adults with spina bifida with or 
without hydrocephalus. J Neurol Neurosurg Psychiatry 2004, 75: $1112-8$

Publish with Bio Med Central and every scientist can read your work free of charge

"BioMed Central will be the most significant development for disseminating the results of biomedical research in our lifetime. " Sir Paul Nurse, Cancer Research UK

Your research papers will be:

- available free of charge to the entire biomedical community

- peer reviewed and published immediately upon acceptance

- cited in PubMed and archived on PubMed Central

- yours - you keep the copyright 